\title{
Resolving The SPlit: Manipulation in the Age OF MusK AND THE Loss CAUSATION MODEL
}

\author{
FREDERICK SPRUNGER*
}

\section{INTRODUCTION}

On average, Twitter users post around 500 million tweets per day and 200 billion tweets per year. ${ }^{1}$ Rarely, however, is a tweet as costly as Elon Musk's post on August 7, 2018: “Am considering taking Tesla private at \$420. Funding secured." Musk sent this tweet from his personal Twitter account for all of his 28.7 million followers to view. ${ }^{3}$ Subsequently, on August 24, 2018, Musk announced via Twitter that Tesla would remain a public company. ${ }^{4}$ Following Musk's announcement that Tesla would remain a public company, the United States Securities and Exchange Commission (SEC) filed a complaint against Musk on September 27, 2018. ${ }^{5}$ The SEC's complaint alleged that Musk violated Section 10(b) of the Securities Exchange Act of 1934 (the "Exchange Act") and SEC Rule 10b-5. ${ }^{6}$ Two days after filing its complaint, the SEC formally announced on September 29, 2018, that it had reached a $\$ 40$ million settlement agreement with Musk. ${ }^{7}$

According to the SEC's complaint, Musk's statement that he was going to take Tesla private once its stock price reached $\$ 420$ per share was "uncertain and

* J.D. Candidate, 2021, Indiana University Robert H. McKinney School of Law; B.A. 2018, DePauw University - Greencastle, Indiana. I would like to start off by thanking the entire editorial team at the Indiana Law Review — specifically, Max Adams and Placido Zambrano for their unwavering patience, support, and guidance. I would also like to thank Professor Frank Sullivan for providing critical feedback, which helped to refine the focus of this Note. And lastly, I would like to thank my family and friends for supporting me throughout my law school journey. A strong support system made this possible.

1. Twitter Usage Statistics, INTERNET Live STATs, https://www.internetlivestats.com/twitterstatistics/ (last visited Oct. 2, 2019) [https://perma.cc/3S6L-CU2B].

2. Elon Musk (@elonmusk), TwiTTER (Aug. 7, 2018, 12:48 PM), https://twitter. com/elonmusk/status/1026872652290379776?lang=en [https://perma.cc/7M6P-52EG] [hereinafter Musk Aug. 7].

3. Elon Musk (@elonmusk), TwITTER, https://witter.com/elonmusk?ref_src=twsrc\% 5Egoogle\%7Ctwcamp\%5Eserp\%7Ctwgr\%5Eauthor (last visited Oct. 2, 2019) [https://perma.cc/9PFW-YARS].

4. Elon Musk (@elonmusk), TwitTer (Aug. 24, 2018, 10:49 PM), https://witter. com/elonmusk/status/1033229945382858753 [https://perma.cc/3Y8A-B5NY] [hereinafter Musk Aug. 24].

5. Complaint, SEC v. Musk, No. 1:18-cv-08865 (S.D.N.Y. Sept. 27, 2018).

6. Id. 93 ; see 15 U.S.C. $§ 78 u(d)$ (2020); see also 17 C.F.R. $§ 240.10 b-5$ (2020).

7. Press Release, SEC, Elon Musk Settles SEC Fraud Charges; Tesla Charged with and Resolves Securities Law Charge (Sept. 29, 2018), https://www.sec.gov/news/press-release/2018226 [https://perma.cc/7ZS5-2FUJ]. 
subject to numerous contingencies." ${ }^{\prime 8}$ After Musk posted the tweet, ${ }^{9}$ Tesla's stock price rose by over $6 \%$ on August 7, 2018, and led to substantial market disruption. ${ }^{10}$ On August 24, 2018, Musk announced that Tesla would remain a public company. ${ }^{11}$ Following Musk's announcement, Tesla's stock price declined $15 \%$ at the end of the next trading day. ${ }^{12}$ To prevent "further market disruption and harm to Tesla's shareholders" and securities fraud, the SEC and Musk reached a settlement which relieved Musk of his position as Chairman of Tesla. ${ }^{13}$ Although the Exchange Act initially addressed securities fraud, ${ }^{14}$ the United States Circuit Courts have yet to adopt a uniform approach to establish loss causation.

With a central focus on the decision in Mineworkers' Pension Scheme v. First Solar, Inc. ${ }^{15}$ this Note argues that: (1) to resolve the circuit split, the courts should implement a corporate finance-based approach to determine loss causation; (2) the court system should collectively adopt an econometric model to calculate loss causation; and (3) the SEC's fine of Elon Musk was appropriate in principle. Because the total value of class action securities fraud settlements approved by courts in 2018 was roughly $\$ 5$ billion - more than three times the total amount approved in 2017-it is important to ensure that courts do not administer securities fraud settlements too liberally. ${ }^{16}$

Part I of this Note outlines SEC v. Musk, Mineworkers', Dura Pharmaceuticals, Inc. v. Broudo, and the three-way circuit split over the necessary requirements for loss causation. Mineworkers' explains how a plaintiff proves loss causation in the Ninth Circuit and the Ninth Circuit's holding that the correct test for loss causation is a general proximate cause test. ${ }^{17}$ Dura expresses the Supreme Court's criticism of the Ninth Circuit's initial holding, and the explicit holding that loss causation must be proven to satisfy Rule $10 \mathrm{~b}-5 .^{18}$ Further, Part I introduces: (1) the theories of proximate cause and loss causation, (2) Rule 10b-5 of the Exchange Act, and (3) an economic model used to measure loss causation. Part II of this Note analyzes the theory of loss causation and the current divide among the circuit courts (with attention to the Musk settlement and the decision in Mineworkers'). Part II also explores the econometric model used to measure loss causation (with attention to the Musk settlement). Lastly, Part III of this Note discusses the policy considerations associated with the current

\author{
8. Id. \\ 9. Musk Aug. 7, supra note 2. \\ 10. Press Release, SEC, supra note 7. \\ 11. Musk Aug. 24, supra note 4. \\ 12. Complaint, supra note 5, 160. \\ 13. Press Release, SEC, supra note 7. \\ 14. 17 C.F.R. $§ 240.10 b-5$ (1951). \\ 15. Mineworkers' Pension Scheme v. First Solar, Inc., 881 F.3d 750 (9th Cir. 2018). \\ 16. Laarni T. Bulan et al., Cornerstone Research, Securities Class action \\ SETTLEMENTS: 2018 REVIEW AND ANALYSIS 3 (2018). \\ 17. Mineworkers', 881 F.3d at 750. \\ 18. Dura Pharm., Inc. v. Broudo, 544 U.S. 336, 338 (2005).
}


landscape of 10b-5 lawsuits on a federal level.

\section{BACKGROUND INFORMATION}

\section{A. SEC v. Musk}

On August 7, 2018, Elon Musk, owner and former Chairman at Tesla, Inc., posted a tweet on Twitter, stating: “Am considering taking Tesla private at $\$ 420$. Funding secured." 19 Tesla, a publicly traded company on the Nasdaq Global Select Market under the ticker symbol TSLA, saw its stock price rise by $6 \%$ and close $10.98 \%$ higher from the previous day. ${ }^{20}$ The SEC noted that Musk often used Twitter to communicate about Tesla's business. ${ }^{21}$ Tesla's Chief Financial Officer described Musk's tweets as "a 'strong channel of marketing' with Musk acting as a 'spokesman' for Tesla.",2

On Friday, August 24, 2018, after the close of official Nasdaq trading, Tesla posted a statement on its blog that indicated Musk no longer planned to take Tesla private. ${ }^{23}$ A short tweet from Musk's personal account, accompanied by a quote on Tesla's blog, explained the decision:

Given the feedback I've received, it's apparent that most of Tesla's existing shareholders believe we are better off as a public company. Additionally, a number of institutional shareholders have explained that they have internal compliance issues that limit how much they can invest in a private company. There is also no proven path for most retail investors to own shares if we were private. Although the majority of shareholders I spoke to said they would remain with Tesla if we went private, the sentiment, in a nutshell, was "please don't do this."24

On August 27, 2018, the next trading day, Tesla stock closed at $\$ 319.27$ per share. ${ }^{25}$ This closing price reflected a $15 \%$ dip from the closing price on August 7 (\$379.57), the date Musk initially tweeted about taking Tesla private. ${ }^{26}$

On September 27, 2018, the SEC filed a complaint against Elon Musk, alleging that Musk violated Section 10(b) of the Exchange Act and Rule 10b-5. ${ }^{27}$ The complaint contained four central assertions: (1) "Musk's August 7 Statements Were Materially False and Misleading"; (2) "Musk Knew or Was Reckless in Not Knowing that His Statements Were False and Misleading"; (3) "Musk Omitted Material Facts"; and (4) "Musk's Tweets Caused Market Chaos

19. Musk Aug. 7, supra note 2.

20. Complaint, supra note $5, \boldsymbol{\Upsilon} 4$.

21. Id. $₫ 12$.

22. $I d$.

23. $I d . ~ \ 58$.

24. $I d . ~ \ 59$.

25. Id. ๆ 60.

26. $I d$.

27. Id. 6 . 
and Harmed Tesla Investors." 28

First, the SEC alleged that Musk's statements on August 7 were misleading because he had not secured nor confirmed commitment from any source to provide funding. ${ }^{29}$ Additionally, "he had never even discussed taking Tesla private at a price of $\$ 420$ per share with the Fund or any other potential investor." ${ }^{30}$ Because of Musk's misleading statements, "investors who purchased Tesla stock in the period after the false and misleading statements but before accurate information was made known to the market" suffered financial harm. ${ }^{31}$

Second, the SEC contended that Musk knew or was reckless in not knowing that his statements were false and misleading for five reasons: (1) Musk posted this tweet in the middle of the trading day ${ }^{32}$; (2) Musk "did not inform Nasdaq that he intended to make [the] announcement," which was a Nasdaq-required rule $^{33}$; (3) Musk knew Tesla's Board of Directors had not voted on the matter and had yet to submit a proposal to discuss the possibility of going private ${ }^{34}$; (4) Musk "had not contacted existing Tesla shareholders to assess their interest in remaining invested in Tesla as a private company"35; and (5) Musk "had not formally retained any legal or financial advisors to assist with a going-private transaction." ${ }^{36}$

Third, the SEC alleged that Musk omitted material facts for two reasons. First, Musk did not attempt to clarify the meaning of his tweet from August 7, 2018, when approached by journalists, reporters, and current Tesla investors. ${ }^{37}$ Second, Musk failed to disclose any potential source of funding in a subsequent Tesla blog post on August 13 (the "Funding Secured Statement"). ${ }^{38}$

Lastly, the SEC contended that Musk's tweets caused market chaos, as evidenced by the fluctuation in Tesla's stock price. ${ }^{39}$ At the end of the trading day on August 7, 2018, Tesla's price per share closed at $\$ 379.57 .^{40}$ By the close of trading on August 27, the first official trading day after Musk issued the statement that he had abandoned his plan to take Tesla private, Tesla's stock had dropped to $\$ 319.44$ per share. $^{41}$

The SEC's claim for relief asserted that Musk violated Section 10(b) of the

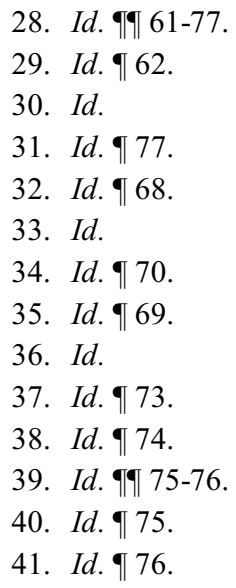


Exchange Act and Rule 10b-5. ${ }^{42}$ The thrust of the claim involved the "employment of manipulative and deceptive devices," which is defined below:

It shall be unlawful for any person, directly or indirectly, by the use of any means or instrumentality of interstate commerce, or of the mails or of any facility of any national securities exchange,

...

(b) To make any untrue statement of a material fact or to omit to state a material fact necessary in order to make the statements made, in the light of the circumstances under which they were made, not misleading, ...

$\cdots$

in connection with the purchase or sale of any security. ${ }^{43}$

The SEC's prayer for relief included two crucial components: ordering Musk to pay civil penalties and prohibiting Musk from acting as an officer or director of any issuer that has a class of securities registered under Section 12 of the Exchange Act. ${ }^{44}$

Two days after the SEC filed the complaint, it was announced that Musk settled the lawsuit. ${ }^{45}$ The settlement included two key provisions: Musk and Tesla would each pay a separate $\$ 20$ million penalty (distributed to investors under a court-approved process), and Musk would step down as Tesla's Chairman and be replaced by an independent Chairman (with eligibility for re-election in three years). ${ }^{46}$ Tesla was certainly not the only company to face a $10 \mathrm{~b}-5$ lawsuit in 2018, as illustrated in the following section.

\section{B. The Mineworkers' Decision}

In Mineworkers' Pension Scheme v. First Solar, Inc., members of the Mineworkers' Pension Scheme brought a securities fraud class action against First Solar, Inc. and its officers, "alleging material misrepresentations designed to inflate stock price, in violation of the Securities Exchange Act." ${ }^{" 47}$ Specifically, the plaintiffs alleged that First Solar, Inc. discovered a manufacturing defect and a design defect in its product and "wrongfully concealed these defects, misrepresented the cost and scope of the defects, and reported false information on their financial statements. ${ }^{.48}$ The United States District Court for the District of Arizona, in addressing the defendants' Motion for Summary Judgment, was required to determine the correct test for loss causation under the Exchange Act. ${ }^{49}$ The court held that the correct test for loss causation is a general proximate cause

42. $I d . \rrbracket 80$.

43. 17 C.F.R. $\S 240.10 b-5$ (2020).

44. Complaint, supra note 5 , at $* 22$.

45. Press Release, SEC, supra note 7.

46. $I d$.

47. Mineworkers' Pension Scheme v. First Solar, Inc., 881 F.3d 750, 750 (9th Cir. 2018).

48. Id. at 752 .

49. Id. 
test and certified the question for interlocutory appeal. ${ }^{50}$

The United States Court of Appeals for the Ninth Circuit affirmed. ${ }^{51}$ To determine the correct test for loss causation, the opinion focuses on one question:

Can a plaintiff prove loss causation by showing that the very facts misrepresented or omitted by the defendant were a substantial factor in causing the plaintiff's economic loss, even if the fraud itself was not revealed to the market, or must the market actually learn that the defendant engaged in fraud and react to the fraud itself? ${ }^{52}$

“The Act defines 'loss causation' as the plaintiff's 'burden of proving that the act or omission of the defendant alleged to violate this chapter caused the loss for which the plaintiff seeks to recover damages." ${ }^{53}$ The court asserted that "[t]o prove loss causation, [the] plaintiffs need only show a 'causal connection' between the fraud and the loss by tracing the loss back to 'the very facts about which the defendant lied." 54 A plaintiff may also prove loss causation if he or she can show "that the stock price fell upon the revelation of an earnings miss, even if the market was unaware at the time that fraud had concealed the miss." 55

The court explained that loss causation is a "context-dependent inquiry" and "simply a variant of proximate cause." 56 "[B]ecause it is the underlying facts concealed by fraud that affect the stock price[,] . . . [t]he 'ultimate issue' under either theory 'is whether the defendant's misstatement, as opposed to some other fact, foreseeably caused the plaintiff's loss." ${ }^{\prime 57}$ In other words, the Ninth Circuit in Mineworkers' adopted a fact-specific, basic proximate cause test to determine loss causation. ${ }^{58}$ This is a pivotal decision, and the court largely based its opinion on arguably the Supreme Court's most influential 10b-5 ruling: Dura Pharmaceuticals, Inc. v. Broudo. ${ }^{59}$

\section{Dura Pharmaceuticals}

In Dura Pharmaceuticals, Inc. v. Broudo, the plaintiffs had filed a classaction lawsuit against Dura Pharmaceuticals ("Dura") on the basis that Dura misrepresented the Food and Drug Administration's (the "FDA") future approval of a new asthmatic spray device, which led plaintiffs to purchase Dura securities

50. Id. at 753 .

51. Id. at 754 .

52. Id. at 753 (citations omitted).

53. Id. (quoting 15 U.S.C. $\S 78 \mathrm{u}-4(\mathrm{~b})(4)$ (2020)).

54. Id. (quoting Nuveen Mun. High Income Opportunity Fund v. City of Alameda, 730 F.3d 1111, 1119-20 (9th Cir. 2013); In re Daou Sys., Inc., 411 F.3d 1006, 1025 (9th Cir. 2005)).

55. Id. at 754 (citing Berson v. Applied Signal Tech., Inc., 527 F.3d 982, 989-90 (9th Cir. 2008); Daou, 411 F.3d at 1026).

56. $I d$. (internal citations and quotation marks omitted).

57. Id. (quoting Lloyd v. CVB Fin. Corp., 811 F.3d 1200, 1210 (9th Cir. 2016)).

58. Id.

59. See Dura Pharm., Inc. v. Broudo, 544 U.S. 336, 336 (2005). 
at an artificially inflated price. ${ }^{60}$ The district court dismissed the complaint and held that the plaintiff "failed adequately to allege 'loss causation'-i.e., a causal connection between the spray device misrepresentation and the economic loss." ${ }^{\prime 61}$ The Ninth Circuit reversed the district court's decision, holding that "a plaintiff can satisfy the loss causation requirement simply by alleging that a security's price at the time of purchase was inflated because of the misrepresentation." 62 Further, the Ninth Circuit held that "plaintiffs establish loss causation if they have shown that the price on the date of purchase was inflated because of the misrepresentation." 63

The Supreme Court granted certiorari and reversed and remanded the Ninth Circuit's decision on the basis that "[a]n inflated purchase price will not by itself constitute or proximately cause the relevant economic loss needed to allege and prove 'loss causation." 64 Second, the Supreme Court found that "[r]espondents' complaint was legally insufficient in respect to its allegation of 'loss causation." " ${ }^{65}$ The Supreme Court noted that there is not necessarily a strong link between the inflated purchase price of a stock and a subsequent economic loss, "since other factors may affect the price. Thus, the most logic alone permits this Court to say is that the inflated purchase price suggests that misrepresentation 'touches upon' a later economic loss, as the Ninth Circuit found." Supreme Court reversed and remanded the Ninth Circuit's decision because the complaint's only allegation was that the plaintiff's "loss consisted of artificially inflated purchase prices." ${ }^{67}$ The Court emphasized that:

Allowing a plaintiff to forgo giving any indication of the economic loss and proximate cause would bring about the very sort of harm the securities statutes seek to avoid, namely, the abusive practice of filing lawsuits with only a faint hope that discovery might lead to some plausible cause of action. ${ }^{68}$

A failure to require plaintiffs to prove that the defendant's misrepresentation proximately caused the plaintiff's economic loss is inconsistent with the law's applicable securities statutes. ${ }^{69}$ In conclusion, the Supreme Court held that the Ninth Circuit's decision in Dura "would allow recovery where a misrepresentation leads to an inflated purchase price, but nonetheless does not proximately cause any economic loss. ${ }^{" 70}$ Although Dura is straightforward in its

60. Id. at 339 .

61. Id. at 336 (citation omitted).

62. Id.

63. Id. at 340 (emphasis in original) (citation omitted).

64. Id. at 336 .

65. Id. at 337.

66. Id. at 336 .

67. Id. at 337 .

68. Id.

69. See id.

70. Id. at 346 . 
analysis, the circuit courts have yet to adopt a bright-line test to determine loss causation harmoniously.

\section{The Three-way Circuit Split}

Presently, the federal circuit courts of appeal "are divided, four to four to two, over whether loss causation requires proof that the market actually learned of and reacted to the defendant's fraudulent misconduct, or whether some lesser showing may suffice." ${ }^{\text {"71 }}$ The First, Fourth, Seventh, and Eleventh Circuits have held that "a plaintiff can recover only for those losses caused by the market's reaction to information that reveals the fraudulent nature of the defendant's conduct." 72 The Second, Fifth, Sixth, and Tenth Circuits maintain a more permissive view of loss causation and hold that:

a plaintiff can establish loss causation by showing that the market reacted to the revelation of the facts concealed by a misrepresentation, whether or not the market learned that those facts were fraudulently omitted from or obscured in the defendant's prior statements. ${ }^{73}$

The Third and Ninth Circuits utilize the least demanding process and hold that "a plaintiff can establish loss causation by showing that the market reacted to some fact attributable to the facts misrepresented or omitted, whether or not the market learns of those underlying facts or that they were fraudulently concealed." ${ }^{\prime 74}$ The present circuit split is a question of federal law with "enormous consequences for the Nation's economy." 75 This issue cannot be explored without a basic understanding of the legal theory of proximate cause.

\section{E. Understanding Proximate Cause}

Black's Law Dictionary provides two formal definitions for proximate cause:

1. A cause that is legally sufficient to result in liability; an act or

71. Petition for Writ of Certiorari, First Solar, Inc. v. Mineworkers' Pension Scheme, No. 18164, 2018 WL 3740587, at *9 (Aug. 6, 2018).

72. Id. at*10-12; see Teachers' Ret. Sys. of La. v. Hunter, 477 F.3d 162, 187 (4th Cir. 2007); Tricont'1 Indus., Ltd. v. PricewaterhouseCoopers, LLP, 475 F.3d 824, 844 (7th Cir. 2007); Meyer v. Greene, 710 F.3d 1189, 1200 (11th Cir. 2013); Mass. Ret. Sys. v. CVS Caremark Corp., 716 F.3d 229, 239 (1st Cir. 2013).

73. Petition for Writ of Certiorari, supra note 71, at*12-13; see In re Williams Sec. Litig. WCG Subclass, 558 F.3d 1130, 1140 (10th Cir. 2009); Ohio Pub. Emps. Ret. Sys. v. Fed. Home Loan Mortg. Corp., 830 F.3d 376, 384 (6th Cir. 2016); Pub. Emps.' Ret. Sys. of Miss. v. Amedisys, Inc., 769 F.3d 313, 325 (5th Cir. 2014); In re Vivendi, S.A. Sec. Litig., 838 F.3d 223, 261 (2d Cir. 2016).

74. Petition for Writ of Certiorari, supra note 71 , at *14-15 (emphasis in original); see Nuveen Mun. High Income Opportunity Fund v. City of Alameda, 730 F.3d 1111, 1120 (9th Cir. 2013); McCabe v. Ernst \& Young, LLP, 494 F.3d 418, 431 (3d Cir. 2007).

75. Petition for Writ of Certiorari, supra note 71 , at $* 9$. 
omission that is considered in law to result in a consequence, so that liability can be imposed on the actor. 2. A cause that directly produces an event without which the event would not have occurred. ${ }^{76}$

When an act or omission directly produces an event that, without the act or omission otherwise would not have occurred, the actor is considered in law to be responsible for the occurrence of the event. ${ }^{77}$ Therefore, if the SEC's complaint against Elon Musk had gone to trial, the SEC would have had to prove that it was more likely than not that in the absence of Musk's tweet on August 7 and his blog posts on August 13 and August 24, Tesla's stock price would not have declined by fifteen percent. Although the legal theory of proximate cause can be difficult to prove in certain situations, it is critical to the fiber of the Exchange Act.

\section{F. The Securities Exchange Act of 1934: Rule 10b-5}

The Securities Act of 1933 and the Securities Exchange Act of 1934 (collectively, the "Exchange Laws"), in large part, "came to exemplify both the New Deal era and the rapid growth of federal government regulation of the business world." 78 The Exchange Laws were designed to restore confidence in the securities markets following the recession in $1929 .{ }^{79}$ The Exchange Act, which cast a much wider net than the 1933 law, was vehemently disputed by New York Stock Exchange President Richard Whitney. ${ }^{80}$ Nevertheless, the House of Representatives passed the Exchange Act by a margin of 281-84 (with 61 abstentions), and the Senate approved the Exchange Act by a margin of 62-13. ${ }^{81}$

In SEC v. Musk, Mineworkers', and Dura, all three defendants were accused of violating Rule 10b-5 ("Employment of manipulative and deceptive devices") of the Exchange Act. ${ }^{82}$ This rule states:

It shall be unlawful for any person, directly or indirectly, by the use of any means or instrumentality of interstate commerce, or of the mails or of any facility of any national securities exchange,

(a) To employ any device, scheme, or artifice to defraud,

(b) To make any untrue statement of a material fact or to omit to state a material fact necessary in order to make the statements made, in the light of the circumstances under which they were made, not misleading, or

76. Proximate Cause, Black's Law Dictionary (8th ed. 2004).

77. See id.

78. Larry Bumgardner, A Brief History of the 1930s Securities Laws in the United StatesAnd the Potential Lesson for Today, 4 J. Global Bus. Mgmt. at 1 (Apr. 2008), www.jgbm.org/page/5\%20Larry\%20Bumgardner.pdf [https://perma.cc/WH7U-2HZV].

79. Id. at 6.

80. Id. at 4 .

81. Id.

82. Complaint, supra note 5, ๆ 6; Dura Pharm., Inc. v. Broudo, 544 U.S. 336, 341-42 (2005); Mineworkers' Pension Scheme v. First Solar, Inc., 881 F.3d 750, 752 (9th Cir. 2018). 
(c) To engage in any act, practice, or course of business which operates or would operate as a fraud or deceit upon any person, in connection with the purchase or sale of any security. ${ }^{83}$

The "common law of deceit subjects a person who 'fraudulently' makes a 'misrepresentation' to liability 'for pecuniary loss caused' to one who justifiably relies upon that misrepresentation." ${ }^{\prime 4}$ In addition, Rule $10 \mathrm{~b}-5$ forbids "the making of any 'untrue statement of a material fact' or the omission of any fact 'necessary in order to make the statements made . . not misleading." "85 The application of Rule $10 \mathrm{~b}-5$ is deeply rooted in the theory of loss causation.

\section{G. Loss Causation and the Model}

An overview of economic theory is integral to understanding the principles of loss causation and stock market fraud. American securities law assumes that the stock market operates by the "efficient market" theory. ${ }^{86}$ The core principle of the efficient market theory is that the economic market responds to the entirety of "available information to assess the present value of future cash flows" of a company, which in turn establishes the stock (or security) price. ${ }^{87}$ Market participants trade in reliance that a stock price "reflect[s] all public information." ${ }^{88}$ Hence, "[u]nderlying the adoption of extensive disclosure requirements was a legislative philosophy: 'There cannot be honest markets without honest publicity. Manipulation and dishonest practices of the marketplace thrive upon mystery and secrecy." 89 The price of a stock "is a dynamic, not a static, concept and the market may re-evaluate and re-price a stock on a daily, hourly or even momentary basis." 90

The introduction of fraudulent information or the omission of crucial information "infuses false (material) information into the [market]." factors affect the overall price of a stock..$^{92}$ In the context of this Note, (1) Elon Musk's tweets and blog posts; (2) First Solar, Inc.'s concealment of product manufacturing defects, misrepresentation of the scope of the defects, and false information on financial statements; and (3) the introduction of false information regarding the FDA's future approval of Dura's asthmatic spray device represent

83. 17 C.F.R. $§ 240.10 b-5$ (2020).

84. Dura Pharm., 544 U.S. at 343 (citing Restatement (Second) of Torts $\S 525$ (AM. LAW INST. 1976)).

85. Id. at 341 (quoting 17 C.F.R. $\S 240.10 \mathrm{~b}-5$ (2004)).

86. Madge S. Thorsen et al., Rediscovering the Economics of Loss Causation, 6 J. Bus. \& SEC. L. 93, 95 (2006).

87. $I d$.

88. Id.

89. Basic Inc. v. Levinson, 485 U.S. 224, 230 (1988) (quoting H.R. REP. No. 1383, at 11 (1934)).

90. Thorsen et al., supra note 86 , at 95 .

91. Id. at 96 .

92. Id. 
the alleged infusion of fraudulent information into the market. The following definitions will be utilized to explain the theory of loss causation:

"price" to mean the price at which a stock actually trades; "inflationary component" or "inflation" to mean the part of the price infused with fraud; "investment loss" to mean the difference between the price actually paid for the stock and the price at which it is sold (or the price on a measurement date required by law); and "inflationary loss" to mean the loss due to the fraud (measured by inflation on the day of purchase minus inflation on the day of sale - or measuring date) ${ }^{93}$

Loss causation begins when fraud leads a stock price to be higher than it should be, the buyer overpays for that stock, and the buyer is unable to recover from his or her overpayment. ${ }^{94}$ The Private Securities Litigation Reform Act of 1995 codified that to prove loss causation in a Rule $10 \mathrm{~b}-5$ action, the plaintiff must "prov[e] that the act or omission of the defendant alleged to violate [section 10(b)] caused the loss for which the plaintiff seeks to recover damages." Standing alone, a dip in stock price "following the revelation of a concealed truth is insufficient to establish loss causation." "In addition, there must be a "causal connection between the material misrepresentation and the loss." ${ }^{.97}$ Plaintiffs rely heavily on expert testimony to establish causal links. ${ }^{98}$

An event study is a regression analysis tool used to assess claims of loss causation, which also controls for factors other than the alleged fraud that affects the stock price. ${ }^{99}$ In other words, an event study "is an examination of the association between news about a company (good, bad, or neutral) and stock price movements." ${ }^{100}$ A typical econometric model used to measure the effect of alleged misrepresentation or a corrective disclosure on a stock price is:

93. Id.

94. Andrew M. Erdlen, Note, Timing Is Everything: Markets, Loss, and Proof of Causation in Fraud on the Market Actions, 80 FordHAM L. REV. 877, 885-86 (2011).

95. Allen Ferrell \& Atanu Saha, The Loss Causation Requirement for Rule 10b-5 Causes of Action: The Implications of Dura Pharmaceuticals, Inc. v. Broudo, 63 Bus. LAW. 163, 164 (2007) (internal citation omitted).

96. Erdlen, supra note 94, at 880 (citing Dura Pharm., Inc. v. Broudo, 544 U.S. 336, 342-43 (2005)).

97. Id. (quoting Dura Pharm., 544 U.S. at 342).

98. Id.

99. Id. at 903 .

100. Thorsen et al., supra note 86 , at 109. 


$$
r_{t}=\ln \left(\frac{p_{t}}{p_{t-1}}\right)=\beta_{0}+\beta_{1} M_{t}+\beta_{2} I_{t}+\sum_{i=1}^{k} \alpha_{i} D_{i}+\varepsilon_{t}
$$

$r=$ the daily return (i.e., logarithmic percent change) of the stock price; $M=$ the return on the market index, such as the S\&P 500 or the Dow Jones Index;

$I=$ the return on an industry index (e.g., S\&P Telecom Index); and

$t=$ the $t^{\text {th }}$ day.

$\ldots D_{k}=k$ day-dummy variables. [T] hat is, they are binary variables, each taking the value of one for the day at issue and a value of zero for all other days. These days may be the days of the alleged misrepresentations or days of the corrective disclosures.

The estimated coefficient of the $i$-th day dummy, $a_{i}$, is a measure of the market and industry-adjusted return, in short the "abnormal return" on the $i$-th day. ${ }^{101}$

This event study uses mathematics to effectively isolate the dissemination of misinformation from other surrounding factors, and "[a] sufficiently large value of the t-statistics (generally greater than 1.96 in absolute value for a $95 \%$ level of confidence) allows the investigator to conclude that the estimated abnormal return on the $i$-th day cannot be explained by chance alone and is therefore attributable to firm-specific news." ${ }^{102}$ Loss causation and event studies work in application as well as theory.

\section{ANALYSIS AND APPLICATION}

\section{A. Breaking Down Loss Causation in Theory}

Without a corrective disclosure on behalf of a publicly traded company, proving loss causation in a 10b-5 lawsuit "can be a daunting task" for a plaintiff. ${ }^{103}$ However, generally speaking, loss causation is a sound legal doctrine that, in most cases, insulates defendants from potentially unnecessary, unfair litigation:

The loss causation requirement allows courts to separate losses attributable to the fraudulent statement from those attributable to other intervening market forces, such as a general downturn in the economy, unexpected increases in the cost of goods (e.g., the price of oil), and

101. Ferrell \& Saha, supra note 95, at 166-67 (citing Nihat Aktas et al., Event Studies with a Contaminated Estimation Period, 13 J. CORP. Fin. 129-45 (2007)); see generally JoHN Y. Campbell et al., The Econometrics of Financial Markets 149-80 (1997).

102. Ferrell \& Saha, supra note 95, at 167 (citing CAMPBELL ET AL., supra note 101, at 166).

103. 4 Thomas Lee Hazen, Treatise on the Law of Securities Regulation $§ 12: 93$ (2019). 
other economic events that may negatively impact the issuer's business. ${ }^{104}$

Although loss causation is regarded as a widely accepted legal principle, the courts are split on "whether a broad or narrow view of loss causation is appropriate in Rule 10b-5 cases." 105 This divergence among the courts boils down to the fact that the proper approach (a broad or narrow view of loss causation) is determined by the facts and circumstances surrounding the case. ${ }^{106}$

The implementation of proximate cause, an inherently ambiguous legal principle described as a "tangle and a jungle, a palace of mirrors and a maze"107 in the Ninth Circuit's Mineworkers' decision, was met with criticism. ${ }^{108}$ A handful of trade groups (the Securities Industry and Financial Markets Association, the Chamber of Commerce, the Pharmaceutical Research and Manufacturers of America, the National Association of Manufactures, and the Business Roundtable) advocated that the Supreme Court should grant certiorari in Mineworkers' for two reasons: (1) the Ninth Circuit's test for proving "loss causation" in private securities actions is overly broad, and (2) the Mineworkers' decision "creates a three-way circuit split that the top court must resolve." 109 The trade groups were correct in one major respect: the courts should resolve the three-way circuit split for loss causation.

To determine loss causation without prejudicing either party in a $10 \mathrm{~b}-5$ lawsuit and subsequently resolve the three-way circuit split, the court's loss causation analysis should be rooted in the basic principles of corporate finance. ${ }^{110}$ To accomplish this goal, the court should answer two questions in its analysis of loss causation: "(i) was the stock price inflated by fraud; and (ii) has the stock price declined because the fraud is no longer propping up the price?"111 To answer these questions, the court only has to understand four central concepts:

(1) $[T]$ he market price of a publicly-traded stock is based on the public's projections of how that company is going to perform in

104. Michael J. McConnell, Supreme Court Clarifies Loss Causation Element for Rule 10b-5 Claim, The Business Suit, DRI, JONES DAY (May 2005), https://www.jonesday.com/ en/insights/2005/05/supreme-court-clarifies-loss-causation-element-for-rule-10b5-claim-ithebusiness-suiti-dri [https://perma.cc/Z32A-JTTZ].

105. HAZEN, supra note 103.

106. Id.

107. Thorsen et al., supra note 86, at 114 (quoting William Prosser, Proximate Cause in California, 38 CALIF. L. REV. 369, 375 (1950)).

108. See Peter H. Hamner, Trade Groups Urge Supreme Court to Review 'Loss Causation' Decision, 24 Westlaw J. Derivatives, no. 22, 2018, at 03.

109. Id.

110. Jay W. Eisenhofer et al., Securities Fraud, Stock Price Valuation, and Loss Causation: Toward a Corporate Finance-Based Theory of Loss Causation, 59 Bus. LAW. 1419, 1441-45 (2004)

111. Id. at $1442-43$. 
the future.

(2) Where a company publicly discloses its present or past financial performance, the market will use this information as an indicator of the company's future cash flows. ... .

(3) [A] disclosure (whether of current performance or anticipated future performance) that causes the market to believe that future performance will fall short of expectations, will deflate a stock price.

(4) If it is later revealed that the initial expectations upon which investors relied were based upon fraudulent reporting of results, investors have been victimized by the fraud, even if disclosure of the fraud was subsequent to the stock price decline. ${ }^{112}$

Moving from a fact-based proximate cause approach to a corporate finance-based approach is beneficial for three reasons. First, the two-prong test does not favor one party over the other and will lead to fair outcomes. Second, the test is straightforward in theory and in application. Third, the test serves as an agreeable option that follows the Supreme Court's holding in Dura, is consistent with Rule $10 \mathrm{~b}-5$, and promotes uniformity across the circuit courts. ${ }^{113}$

The most desirable characteristic of this two-prong test is that it strikes a balance and provides plaintiffs a clear path to recovery without unjustly prejudicing defendants. On the one hand, some courts hold that loss causation cannot be found if disclosure of fraud does not immediately follow a decline in stock price. ${ }^{114}$ This stance is unfair to plaintiffs "because there are clear cases of fraud where the stock declined substantially prior to the formal announcement of the fraud, and thus there was little room for further decline after the fraud was announced." 115

On the other hand, some courts have afforded plaintiffs recovery on the sole basis of reliance without proof that the loss was related to the alleged fraud. ${ }^{116}$ This approach is unfair to defendants because the plaintiff is hardly required to meet any burden of proof, which is contrary to the Supreme Court's ruling in Dura (which illustrates that the plaintiff must establish a causal connection to prove loss causation): "ordinary pleading rules are not meant to impose a great burden upon a plaintiff. But it should not prove burdensome for a plaintiff who has suffered an economic loss to provide a defendant with some indication of the loss and the causal connection that the plaintiff has in mind." 117

The recommended two-prong test shifts focus away from a timeline-specific

112. Id. at 1442

113. See id.

114. Id. at 1419-20.

115. See id. at 1441-42 (citing Danis v. USN Commc'ns, Inc., 73 F. Supp. 2 d 923 (N.D. Ill. 1999); Greenberg v. Crossroads, 364 F.3d 657 (5th Cir. 2004)).

116. Id. at 1442 (citing Danis, 73 F. Supp. 2d at 923; In re Initial Pub. Offering Sec. Litig., 241 F. Supp. 2d 281 (S.D.N.Y. 2003)).

117. Dura Pharm., Inc. v. Broudo, 544 U.S. 336, 347 (2005). 
analysis of loss causation and provides plaintiffs and defendants equal protection in $10 \mathrm{~b}-5$ actions. In one respect, this approach allows plaintiffs to recover under a theory of loss causation in cases where fraud did occur (even if the timeline of events did not perfectly match up). Nonetheless, it protects defendants from unscrupulous claims of loss causation based solely on reliance.

Second, the two-prong test is straightforward in theory and application. As previously stated, the court must only understand four basic concepts to implement the test. ${ }^{118}$ The next section of this Note applies the two-prong test to (1) SEC v. Musk, and (2) Mineworkers' to illustrate its usefulness in theory and in practice.

\section{B. Applying the Theory: SEC v. Musk and Mineworkers'}

To answer the first question of the two-prong test in SEC v. Musk (was the stock price inflated by fraud?), it is important to examine the nature of Musk's comments, and how the public perceived these comments. First, Musk's tweet on August 7, 2018, ${ }^{119}$ noted that he had "funding secured" to take the company private, which indicated that "all it would take to de-list the company from the stock market, then, was the approval of its shareholders." ${ }^{20}$ This tweet was also accompanied by a supplemental blog post, which added context to the rationale behind the decision to take Tesla private. ${ }^{121}$ At the outset, it should be noted that Tesla's Chief Financial Officer described Musk's use of his Twitter account as being a "spokesman" for Tesla. ${ }^{122}$ From the perspective of Tesla's shareholders, this tweet certainly could have been perceived as serious in nature, and the market reaction suggests that Musk's statements (tweet and blog post) did inflate the stock price. ${ }^{123}$ It is also important to understand that when a company transitions its stock from publicly traded to private, the company repurchases its shares from the shareholders (at market price) at the time of transition. ${ }^{124}$

When Musk posted the tweet about taking the company private, Tesla's stock price per share was around $\$ 372 .{ }^{125}$ The assertion that Musk would take Tesla

118. Eisenhofer et al., supra note 110, at 1441-45.

119. See Musk Aug. 7, supra note 2 .

120. Sean O'Kane \& Elizabeth Lopatto, Elon Musk Sued by SEC over 'Funding Secured' Tweet, VERGE (Sept. 27, 2018), https://www.theverge.com/2018/9/27/17911428/sec-lawsuit-elonmusk-tesla-funding-tweet [https://perma.cc/96MV-6UTD].

121. Elon Musk, Taking Tesla Private, Tesla (Aug. 7, 2018), https://www.tesla.com/blog/ taking-tesla-private?redirect=no [https://perma.cc/67FK-YTR2].

122. Complaint, supra note 5, $₫ 12$.

123. Id. $₫ 4$.

124. Tom Huddleston Jr., Elon Musk Says He Wants to Take Tesla Private at over $\$ 70$ Billion - Here's What That Means, CNBC (Aug. 8, 2018), https://www.cnbc.com/2018/08/08/elon-muskwants-to-take-tesla-private--heres-what-it-means.html [https://perma.cc/GN8Y-ULJG].

125. Lucas Fortney, How Tesla's Share Price Dropped $\$ 100$ in 80 Days, InvestopediA, https://www.investopedia.com/investing/how-teslas-share-price-dropped-100-80-days/ (last updated June 6, 2019) [https://perma.cc/3NF7-RYUA]. 
private once the stock price reached $\$ 420$ per share represented "more than a $20 \%$ premium over the market share price of $\$ 370$ at that date." ${ }^{126}$ Tesla's stock price rose more than $8.5 \%$ on the afternoon of that tweet, which suggests that investors lunged at the opportunity to gain on the proposed buyout, which would have been the largest in history. ${ }^{127}$ Taken together with the fact that Musk's tweet and blog post were, in fact, untruthful and misleading, ${ }^{128}$ it can be inferred that the stock price was inflated by fraud. There is ample evidence to support that, as a company, Tesla had hardly entertained the notion of taking the company private, especially at a whopping price of $\$ 420$ per share. ${ }^{129}$

To answer the second question of the two-prong test (has the stock price declined because the fraud is no longer propping up the price?), it is imperative to refer back to one of the previously discussed basic tenets of corporate finance. ${ }^{130}$ This tenet provides that reliance on the dissemination of false information can often lead to the assertion that investors were victimized by fraud. ${ }^{131}$ Although Musk did not report fraudulent financial results, the nature of Musk's behavior (and the subsequent market reaction) certainly lends credence to the theory that Musk's posts on social media led investors to rely on false, untrue information. ${ }^{132}$ When Musk later disclosed that Tesla would not transition to a private company, the stock price plummeted. ${ }^{133}$ This market behavior indicates that the stock price declined because fraud (the false claim embedded in Musk's tweet on August 7) was no longer "propping up the price." 134 In the context of SEC v. Musk, it is abundantly clear that both questions in the twoprong test were answered in the affirmative. Therefore, the SEC's assertion of loss causation, in this case, was legitimate. ${ }^{135}$

Application of the proposed two-prong test to Mineworkers' will be slightly different than the application to SEC v. Musk. The biggest difference between the two cases is that in Mineworkers', First Solar, Inc. was alleged to have reported false information in its financial statements. ${ }^{136}$ In this case, the first and second

126. $I d$.

127. Annie Gaus, Here's How Much Taking Tesla Private Could Cost-and Who Might Foot the Bill, TheSTREeT (Aug. 8, 2018), https://www.thestreet.com/technology/how-much-taking-teslaprivate-could-cost-14678229 [https://perma.cc/D6JS-CEE9].

128. Complaint, supra note 5, 9 ๆ 61-62.

129. Fortney, supra note 125.

130. See Eisenhofer et al., supra note 110, at 1441-45.

131. See id.

132. Fortney, supra note 125.

133. Id.

134. See Complaint, supra note 5, 9 75-76 (stating that at the end of the trading day on August 7, 2018, Tesla's closing stock price per share was $\$ 379.57$, and that by the close of trading on August 27, the first official trading day after Musk issued the statement that he had abandoned his plan to take Tesla private, Tesla's stock had dropped to $\$ 319.44$ per share).

135. See id.

136. Mineworkers' Pension Scheme v. First Solar, Inc., 881 F.3d 750, 753 (9th Cir. 2018) (citing Dura Pharm., Inc. v. Broudo, 544 U.S. 336, 347 (2005)). 
questions work in tandem to conclude that First Solar, Inc.'s stock price was artificially inflated by fraud, and the stock price declined because the fraud was no longer propping up the price. Posting materially, blatantly false financial information did not provide First Solar, Inc.'s investors any reason to believe that the company was actually dealing with a rather significant product defect. ${ }^{137}$

Mineworkers' states that 'the ultimate issue is whether the defendant's misstatement, as opposed to some other fact, foreseeably caused the plaintiff's loss." ${ }^{138}$ In this case, the company's failure to disclose the proper financial information kept the stock price at nearly $\$ 300$ per share. ${ }^{139}$ The fact that this false information kept the stock price artificially propped at $\$ 300$ per share is evidenced by the fact that, when the true company information was disclosed, the company's stock price plummeted to nearly $\$ 50$ per share. ${ }^{140}$

A close analysis of Mineworkers' provides that First Solar, Inc.'s stock price was inflated by fraud, which manifests itself in different forms. In other words, it is critical to understand that the failure to disclose complete and correct information (which was the case in Mineworkers') can be just as harmful to investors as the release of blatantly false information (which was the case in $S E C$ v. Musk). The application of the two-prong test in SEC v. Musk and Mineworkers' suggests that the claim of loss causation in both cases was legitimate. The fact that the two-prong test has been effectively applied in two cases with largely different fact patterns illustrates the test's versatility, flexibility, and ability to return consistent verdicts across the circuit courts.

\section{Consistency Is Key: Why the Two-Prong Test Promotes Uniformity Across the Circuit Courts and Supports Dura}

The two-prong loss causation test (1) promotes uniformity because it is applicable across the Circuit courts, (2) is supported by the Supreme Court's holding in Dura, and (3) aligns with Rule 10b-5. The fact that the circuit courts are at odds when it comes to the analysis of loss causation is an issue, and a fixable one at that. If the bright-line, two-prong test is universally applied and the court gives factors such as foreseeability and proximate cause less credence, there is a compelling chance that the courts will issue consistent verdicts when provided equivalent facts. ${ }^{141}$

The Supreme Court's holding in Dura is consistent with the two-prong test. In Dura, the Supreme Court makes it abundantly clear that the plaintiff must meet a sufficient burden to prove loss causation (a burden that the two-prong test also

137. Id. at 752 ("First Solar discovered a manufacturing defect causing field power loss and a design defect causing faster power loss in hot climates.").

138. Id. at 753 (quoting Lloyd v. CVB Fin. Corp., 811 F.3d 1200, 1210 (9th Cir. 2016)).

139. Id. at 752 .

140. Id.

141. See Eisenhofer et al., supra note 110; compare In re Merrill Lynch \& Co. Research Reports Sec. Litig., 273 F. Supp. 2d 351 (S.D.N.Y. 2003), with Burstyn v. Worldwide Xceed Grp., Inc., No. 01 Civ. 1125(GEL), 2002 WL 31191741 (S.D.N.Y. Sept. 30, 2002). 
endorses):

The securities laws make clear Congress' intent to permit private securities fraud actions only where plaintiffs adequately allege and prove the traditional elements of cause and loss, but the Ninth Circuit's approach would allow recovery where a misrepresentation leads to an inflated purchase price, but does not proximately cause any economic loss. ${ }^{142}$

That said, Dura and the two-prong test also support the notion that the defendant should be given a fair shake in 10b-5 lawsuits and acknowledge that factors other than alleged fraud may affect stock prices. ${ }^{143}$ By taking an expansive view (considering the entirety of the situation) and not simply conducting a timelinebased analysis, Dura and the two-prong test are rooted in the same foundational principles. ${ }^{144}$ The courts' willingness to collectively adopt the two-prong test in the context of loss causation analysis would be a step in the right direction.

The Exchange Act and Rule 10b-5 were implemented for two primary reasons: (1) to deter and punish fraud and deceptive practices, and (2) restore trust in the stock market following the crash in $1929 .{ }^{145}$ Although the stock market and technology have evolved drastically, and Congress most recently amended the rule in 2014, ${ }^{146}$ the central intention remains unchanged. Because it considers a myriad of factors, adheres to the traditional legal theory of proximate cause, and adopts basic theories of corporate finance, the two-prong test is applicable across different fact sets and effectively promotes the goals of the Exchange Act and Rule 10b-5. To ensure that loss is analyzed and calculated correctly, the courts should combine the two-prong loss causation test with an econometric model (that is specifically designed to calculate loss). In the context of SEC v. Musk, the following section illustrates the loss causation model (in the form of an event study) in practice.

\section{Breaking Down the Loss Causation Model}

Although the holding in Dura is sound in principle, it did not discuss

142. Dura Pharm., Inc. v. Broudo, 544 U.S. 336, 337 (2005).

143. Id. at 336 ("[T] he logical link between the inflated purchase price and any later economic loss is not invariably strong, since other factors may affect the price.").

144. Id. at 342 ("We begin with the Ninth Circuit's basic reason for finding the complaint adequate, namely, that at the end of the day plaintiffs need only 'establish,' i.e., prove, that 'the price on the date of purchase was inflated because of the misrepresentation.' In our view, this statement of the law is wrong. Normally, in cases such as this one (i.e., fraud-on-the-market cases), an inflated purchase price will not itself constitute or proximately cause the relevant economic loss." (emphasis in original)).

145. Securities and Exchange Act Rule 10b, FindLaw, https://consumer.findlaw.com/ securities-law/securities-and-exchange-act-rule-10b.html (last visited Feb. 12, 2021) [https://perma. cc/9BZH-ZRNQ].

146. Id. 
econometrics, how damages should be measured, finance theory, or other related subjects. ${ }^{147}$ Following Dura, "[c]ourts have plunged into questions of economic loss often on the pleadings or otherwise undeveloped records, becoming deeply mired in "proximate cause." 148 As discussed earlier, although proximate cause should be considered in the analysis of loss causation, the central focus should be on the corporate finance-based two-prong test. ${ }^{149}$ Although this test is effective, it should not stand alone. Instead, it should be implemented in tandem with its economic counterpart: an event study analysis which is discussed in Section I.G of this Note. Unfortunately, economic analysis has been utilized very rarely to establish loss causation, much to the dismay of many legal scholars and economists: "courts have often had to address the adequacy of loss causation and damages issues in a bare-bones context, most often a pleading. This means that concepts of loss have developed somewhat in a vacuum, uninformed by what evidence would actually be required and adduced at the proof stage." 150

The event study regression model should be implemented because it possesses the ability to identify the root of loss causation: inflationary loss. ${ }^{151}$ As previously discussed, inflationary loss (what an investor loses to fraud) is distinguishable from investment loss (what an investor loses in the stock market); however, the concepts are sometimes mistakenly intertwined. ${ }^{152}$ The event study equips the court with the necessary tools to bifurcate the two concepts, and even can "separate out the effects of company-specific news on the stock price from the effects of market or industry forces on the price, thereby identifying the 'true' price and the inflationary component thereof." 153 An event study, which accounts for nearly every quantifiable factor in its calculation of loss causation, should be embraced and utilized by the courts.

Elon Musk agreed to settle with the SEC in an unprecedentedly timely fashion, which indicates at least one of two things: (1) Musk either knew his actions were inappropriate and wrong, or (2) Musk knew he would not have been successful if the complaint had been brought to trial. ${ }^{154}$ Although the SEC and Musk did settle, it is extremely important to ensure that the SEC properly calculated the damages. It is important to note that in a 10b-5 action, an investor's damages are typically "calculated as the out-of-pocket loss that was suffered." 155 An out-of-pocket loss is "measured as the difference between the purchase price and 'true value' of the stock (i.e., the price at which the stock would have sold

147. See Thorsen et al., supra note 86 , at 116 .

148. Id. at 113 .

149. See Eisenhofer et al., supra note 110, at 1424.

150. Thorsen et al., supra note 86, at 113.

151. See Kristin M. Feitzinger, Cornerstone Research, Estimating Recoverable Damages in Rule 10B-5 Securities Class Actions 8-10 (2014).

152. See Thorsen et al., supra note 86, at 97.

153. Id. at 109.

154. Press Release, SEC, supra note 7.

155. Eisenhofer et al., supra note 110, at 1424 (citation omitted). 
absent the alleged misrepresentations or omissions)." ${ }^{156}$ Although this formula is fairly simple to understand conceptually, it would be nearly impossible to calculate accurately without the implementation of an event study. ${ }^{157}$ For example, the courts may take this formula at face value and fail to consider external factors that fluctuate stock prices, which would likely lead to wholly inaccurate damages calculations. ${ }^{158}$ Although an event study provides critical information to calculate an investor's damages accurately, it "does not itself comprise a reliable damages analysis." ${ }^{159}$ That is why an event study should be taken in conjunction with the two-prong loss causation test to provide accurate damages calculations.

In the case of SEC v. Musk, the most efficient way to calculate Tesla investors' damages is through: (1) an event study, (2) the two-prong loss causation test (which is rooted in corporate finance theory), and (3) an intra-day stock price analysis. The central benefit of an intra-day stock price analysis is its ability to "disaggregate the stock price effects of multiple announcements that occur within the event study's analysis window." ${ }^{160}$ In SEC v. Musk, an intra-day stock price analysis would likely support the SEC's contention that Musk's tweet on August 7, which infused false information into the market, triggered investors to purchase Tesla stock. ${ }^{161}$ Under the two-prong loss causation test, it would be adduced that this tweet "propp[ed] up the [stock] price," ${ }^{162}$ leading to an inflationary loss for investors. The use of an event study helps the court isolate the inflationary loss of Musk's one tweet and reduces the probability of overstating or understating an investor's 10b-5 damages. ${ }^{163}$ The complexity associated with the damage calculation process in SEC v. Musk illustrates the assertion that, if possible, courts should implement theories of corporate finance and utilize an event study analysis. Further, given the recent size and frequency of $10 \mathrm{~b}-5$ actions, ${ }^{164}$ it is critical to ensure that damages are awarded correctly. When contemplating the landscape of 10b-5 lawsuits - both present and future - there are a pair of central policy considerations that federal legislators should take into account.

156. Id. (citation omitted).

157. See generallyid.

158. See generallyid. at 1425 .

159. FEITZINGER, supra note 151, at 13.

160. See id. at 12.

161. Fortney, supra note 125 ("Although the Tesla CEO owns $20 \%$ of the company, purchasing the remaining $80 \%$ of the stock at $\$ 420$ per share would cost about $\$ 72$ billion, making it the largest corporate buyout in history.").

162. Eisenhofer et al., supra note 110, at 1443.

163. See Feitzinger, supra note 151 , at 8.

164. See BUlAn ET AL., supra note 16. 


\section{POLICY CONSIDERATIONS}

\section{A. Increase the Predictability of 10b-5 Lawsuits}

The first policy consideration that federal legislators should consider is the current unpredictability of Rule 10b-5 lawsuits. ${ }^{165}$ This unpredictability is twofold: (1) Will the court find loss causation, and (2) will the court correctly calculate damages? As stated earlier, loss causation analysis predicated on proximate cause increases the chance of inconsistent verdicts across the courts when presented with equivalent facts, ${ }^{166}$ and can lead to confusion across the courts: "As arcane as any legal concept, proximate cause deals with the twin inquiries of what event in a chain of events can be fairly said to have caused a consequence and what policy choices should be made to fairly limit a defendant's liability." 167 The implementation of a bright-line, two-prong loss causation test that de-emphasizes the timeline-specific analysis related to inflationary loss provides the courts with a viable option to resolve the three-way circuit court split. As demonstrated in Part II of this Note, the two-prong test requires only a basic understanding of corporate finance theory ${ }^{168}$ and is easily applicable to multiple fact sets. This two-prong test grants the courts (across the board) an opportunity to consistently determine whether loss causation is present in a $10 \mathrm{~b}-5$ lawsuit.

The Exchange Act was designed and implemented to promote stock market transparency, and the "overriding goal of the Rule 10b-5 suit must be deterrence." 169 In theory, Rule 10b-5 should also serve as "a reliable measure of liability for market participants." ${ }^{170}$ Currently, investors' liability is unpredictable, which "does nothing to deter corporate mischief." 171 The perfect example of the unpredictability of 10b-5 lawsuits is the verdict in In re Vivendi Universal, S.A. Securities Litigation. ${ }^{172}$ One of the critical reasons In re Vivendi Universal is marked as unpredictable is because the "jur[y's] findings of share price inflation on a per-day basis did not match the evidence adduced at trial." 173 Although the

165. See Erdlen, supra note 94, at 918 .

166. Eisenhofer et al., supra note 110, at 1442 ("Other courts (many in the Second Circuit) have tried to impose the 'foreseeability' test used for proximate cause in tort cases, but that test has effectively allowed courts to reach contrary results on equivalent facts.").

167. Thorsen et al., supra note 86, at 113 (footnote omitted).

168. See Eisenhofer et al., supra note 110, at 1441-45.

169. See Erdlen, supra note 94, at 918.

170. See id.

171. Id.

172. In re Vivendi Universal, S.A. Sec. Litig., 765 F. Supp. 2d 512 (S.D.N.Y. 2011); see also Erdlen, supra note 94, at 914 ("In 2002, shareholders of Vivendi Universal, S.A. sued the corporation and several of its officers, alleging that Vivendi violated the federal securities laws, including Section 10(b) of the ' 34 Act. The plaintiffs claimed that the defendants misrepresented Vivendi's liquidity condition during a class period stretching from October 2000 to August 2002.”).

173. See Erdlen, supra note 94, at 918. 
jury determined that the defendants were liable for actionable misrepresentations, "the difficulties inherent in linking specific misstatements to inflation resulted in chaotic verdicts." 174 Further, the verdict in In re Vivendi Universal was unpredictable because, "[r]ather than conducting an event study to ascertain what disclosures inflated the value of the security, the plaintiffs' event study examined the gradual materialization of the fraud over those nine dates." ${ }^{175}$ This supports the contention that the implementation of a bright-line, two-prong test coupled with an event study would increase the predictability of $10 \mathrm{~b}-5$ lawsuits. It is the responsibility of the courts to "fashion rules that strengthen the logical connection between liability and measurable loss to prevent further irrational verdicts." ${ }^{\text {"176 }}$ An easily applicable two-prong test would likely yield rational, more consistent verdicts.

\section{B. Size and Frequency of Actions}

The second central policy consideration that federal legislators should consider is the steady increase in size and frequency of 10b-5 lawsuits. In 2018, the courts approved over $\$ 5$ billion in class-action securities fraud settlements, which is more than three times the amount approved in 2017. ${ }^{177}$ Further, "[c]ompared to the historically low levels in 2017, in 2018 the average settlement amount more than tripled to $\$ 64.9$ million, while the median settlement amount (representing the typical case) more than doubled to $\$ 11.3$ million." 178

Although the frequency of litigation is eye-opening, the more glaring concern is that the increase in securities fraud settlements implies that "defendants may feel under siege." ${ }^{\prime 79}$ As previously stated, an event study model rooted in principles of econometrics and corporate finance theory most accurately measures inflationary loss. Therefore, federal legislators should work to develop an event study that is universally implemented across court systems. Taking this step will ensure that defendants do not face excessive SEC fines and settlement amounts.

A closer look at the raw numbers associated with Rule $10 \mathrm{~b}-5$ actions provides the undeniable fact that $10 \mathrm{~b}-5$ settlement amounts are steadily increasing in value. ${ }^{180}$ Although an increase in the total amount of settlement dollars was driven in large part by "a small number of very large settlements,"

174. Id.

175. Id. at 915 (citing Vivendi Universal, 765 F. Supp. 2d at 561).

176. Id. at 918 .

177. BULAN ET AL., supra note 16, at 1.

178. Id.

179. John C. Coffee, Jr., The Changing Character of Securities Litigation in 2019: Why It's Time to Draw Some Distinctions, CLS Blue Sky Blog (Jan. 22, 2019), http://clsbluesky. law.columbia.edu/2019/01/22/the-changing-character-of-securities-litigation-in-2019-why-its-timeto-draw-some-distinctions/ [https://perma.cc/CDR8-HBFP].

180. See Bulan ET AL., supra note 16.

181. Kevin LaCroix, Cornerstone Research: Securities Suit Settlement Size Increased in 2018, D\&O DIARY (Mar. 26, 2019), https://www.dandodiary.com/2019/03/articles/securities- 
cause for concern. Stanford Law Professor Joseph Grundfest offered that larger settlement amounts are particularly troubling for publicly traded corporations: "Increased payouts may pressure insurance carriers to raise the rates they charge and the retentions they impose-which could be challenging developments for corporations, boards, and executives." ${ }^{182}$ Although it is difficult to attribute the increase in settlement amount to a single figure, "the answer appears to relate primarily to the potential resources available to fund the settlement." ${ }^{\prime 83}$ This observation is troubling because it lends credence to the hypothesis that large, publicly traded companies may be overexposed to $10 \mathrm{~b}-5$ lawsuits simply because of their market presence. If the circuit courts adopt an event study regression model to calculate loss causation, the number of settlements in 10b-5 lawsuits will likely decrease.

Similar to an increase in $10 \mathrm{~b}-5$ settlement amounts, the frequency of $10 \mathrm{~b}-5$ lawsuits is also an area of concern. A staggering $8.77 \%$ of all publicly traded companies were sued in securities class actions in 2018 alone - this is the highest litigation rate since $2006 .{ }^{184}$ If this trend continues, publicly traded companies face a one in twelve chance of attracting a securities fraud class-action lawsuit. ${ }^{185}$ This increase in litigation inherently increases the cost of doing business, as the "risk of liability would force companies to defend frivolous claims." American companies' exposure to liability "may deter overseas firms from doing business in America." 187 This could lead to rising industry prices and make investment in American markets less profitable. ${ }^{188}$ A decrease in the profitability of American markets could have a ripple effect across the industry and spurn future economic development. This potential domino effect is something that federal legislators should consider in the context of the recent increase in the frequency of 10b-5 lawsuits.

\section{CONCLUSION}

Although the Supreme Court's holding in Dura was straightforward, it left the circuit courts fragmented and at odds over the proper standard to determine loss causation. This Note began by outlining the theories of loss causation and

\footnotetext{
litigation/cornerstone-research-aggregate-average-and-median-securities-suit-settlements-increasedin-2018/ [https://perma.cc/Q638-CKF5].

182. Id.

183. BULAN ET AL., supra note 16, at 2.

184. Coffee, Jr., supra note 179.

185. Id.

186. W. Taylor Marshall, Note, Securities Law-The Securities Exchange Act of 1934-'Round and 'Round We Go: The Supreme Court Again Limits the Circumstances in Which Federal Courts May Hold Secondary Actors Liable Under Section 10(b) and SEC Rule 10b-5. Stoneridge Investment Partners, LLC v. Scientific-Atlanta, Inc., 128 S. Ct. 761 (2008), 31 U. ARK. LitTle Rock L. ReV. 197, 233 (2008).

187. Id.

188. Id.
} 
proximate cause, Rule 10b-5 of the Securities Exchange Act of 1934, and the current landscape of how the circuit courts determine loss causation. This Note offered a two-prong, loss causation test rooted in basic theories of corporate finance to resolve the split. The two-prong test should be supplemented with an event study (to accurately calculate an investor's inflationary loss) to ensure that damages are neither overstated nor understated. Further, based on economic theory and the application of the two-prong test and an event study, the SEC's complaint against Elon Musk was sound in principle. Therefore, this Note concludes that Musk was correct to settle.

Further, this Note offered that federal legislators should consider adopting a two-fold loss causation analysis, focused on a bright-line, two-prong test accompanied by an event study. This framework would be beneficial for four primary reasons. First, the bright-line test will increase the general predictability of 10b-5 lawsuits and help juries return verdicts that are consistent with the facts. Second, the bright-line test will ensure that defendants are protected from frivolous Rule 10b-5 claims. However, it is important to note that in cases such as SEC v. Musk and In re Vivendi Universal, the defendants were guilty of actions that are punishable under Rule 10b-5. Third, the use of a bright-line test supplemented by an event study will ensure that damages are calculated fairly and appropriately, regardless of a company's "potential resources available to fund the settlement" across the board. ${ }^{189}$ And lastly, the bright-line test will help to ensure an increase in 10b-5 litigation does not make American markets unjustifiably less profitable.

189. BulAN ET AL., supra note 16, at 2 . 